Pak. j. sci. ind. res. Ser. B: biol. sci. 2021 64B(3) 283-287

\title{
Effect of Different Doses of Compost on Growth and Yield of Cotton
}

\author{
Meer Muhammad Kolachi*, Ashfaque Ahmed Nahiyoon, Ghulam Nabi Sehto \\ and Babar Zaman \\ (CABI) Central and West Asia, Rawalpindi, Pakistan
}

(received August 7, 2018; revised April 04, 2019; accepted April 8, 2019)

\begin{abstract}
Cotton is main cash crop of Pakistan that is also called "white gold". Majority of farmers from Punjab and Sindh cultivate it and earn high value in market to improve their livelihood. It is very important crop for cotton industry and people because, it provide raw material to industry and job to workers who serve in this sector from sowing to harvesting,ginning to weaving and selling. Cotton sector play important role in National economy as it is also a rich source of edible oil. In current scenario, growing cotton is becoming costly due to use of expensive inputs. To play part in reducing input cost of cotton present study conducted. The study aimed to evaluate efficacy of compost developed from crop refuse at zero cost. For this purpose performance of three cotton varieties MNH 886, FH 142 and IR 901 checked at five doses 100 $\mathrm{Kg}, 200 \mathrm{Kg}, 300 \mathrm{Kg}, 400 \mathrm{Kg}$ and $500 \mathrm{Kg}$ of compost per acre. Results revealed that MNH 886 performed good among all three varieties on all doses followed by FH 142 and IR 901 respectively. MNH 886 performed good than all others, where maximum seed germination recorded $72.67 \%$, plant height 138.93 $\mathrm{cm}$, root length $35.43 \mathrm{~cm}$, numbers of branches 11.56 , numbers of bolls 45.78 and yield $1840 \mathrm{Kg}$ per acre on $500 \mathrm{Kg}$ compost per acre recorded.However, minimum seed germination $48.56 \%$, plant height 93.02 $\mathrm{cm}$, root length $25.24 \mathrm{~cm}$, numbers of branches 8.67, numbers of bolls 11.89 and yield was recorded 1042 $\mathrm{Kg}$ on $100 \mathrm{Kg}$ compost per acre. Same trend of maximum growth at $500 \mathrm{Kg}$ and minimum at $100 \mathrm{Kg}$ compost observed on FH142 and IR901.
\end{abstract}

Keywords: compost, cotton yield,white gold.

\section{Introduction}

Cotton Gossypium hirsutum commonly known as "white gold" is an important cash crop for Pakistan. It normally grows in plains of Punjab and Sindh for its high value to growers and industry. Growers chiefly grow it for its fibre, that in manufacturing cloth, making threads, mixing and extracting oil and using with other fibres. Ghazala and Rasul (2010) and Arain (2012) in Pakistan has agriculture-based economy which runs textile industry. Textile industry serves as backbone of agriculture economy that maintains $8 \%$ share in gross domestic product, accounts about $53 \%$ share in national exports and employees about $40 \%$ of industrial labour force. Being fourth largest producer of cotton Pakistan contributes $5 \%$ to the global spinning capacity after India and China. The country produced 12.769 million bales during 2013/14 and took its part in earning foreign exchange. During 2013-14 agriculture sector recorded a growth of $2.1 \%$ against the growth of $2.9 \%$ previous year. Anonymous (2013 and 2012) the decline in growth due to extreme weather. In current situation, growers

*Author for correspondence; E-mail: meer157@gmail.com have reduced cotton area due to weather threats and costly inputs of (fertilizer, pesticide and seeds) as per acre, profit of cotton is reducing and compelling farmers to shifting from cotton to minor short duration crops. Compost refers to biological decomposition and stabilization of organic substrates under conditions that allow high temperatures to decompose material and convert it into viable fertilizer; microbes do this all Diaz and De Bertoldi (2007), the term compost extracted from Latin word compostium, which means mixture, it is the process which transforms organic wastes into firm nutritive products such as fertilizer for soil. Kumar et al. (2011) and Vinceslas-Akpa and Loquet (1997) developed by accelerating activity of aerobic micro organisms such as bacteria,their accelerated growth on plant material. It is ensured by providing oxygen, moisture and food to them in order to grow and multiply. Microbes generate heat, water vapours and carbon dioxide as they transform raw materials into a stable soil condition. When this process reach at zenith it cause de-composition of the material. Use of compost improves soil structure, porosity, density and consequently gives better environment to plant root. It increases infiltration 
and permeability of heavy soils and reduces erosion and runoff from the soil. By improving physical condition of soil, compost improves water holding capacity, thus reducing water loss and leaching in sandy soils and provides variety of macro and micronutrients. Compost stabilizes soil $\mathrm{pH}$ and supplies significant quantities of organic matter to soil. It acts as disease suppressant, as it is associated with biological control agents to alleviate plant pathogens. It kills all harmful micro-organisms due to the microbial generated temperature by Pugliese et al. (2011) and Anonymous (2008). When soil organisms are active in soil, plants become healthy due to increasing organic matter content. Sufficient levels of organic matter also encourage the growth of earthworms, which increase water infiltration and aeration through tunnelling. Soil health is directly proportional to availability of organic matter. Microorganisms involved in the composting process are bacteria, protozoa, actin-omycetes and fungi. These micro-organisms develop in compost and propagate within soil media. Some micro-organisms such as fungi come in symbiosis with plant roots and assist plant roots for extraction of nutrients from soils Anonymous (2008).

\section{Material and Methods}

Present study conducted to check efficacy of organic fertilizer (compost) made from farm yard manure, crop refuse (chopped sugarcane leaves), press mud (of sugar mill), EM (effective micro-organisms) solution, chopped Bar seem and urea. Fifteen farmers of better cotton project selected at tehsil Khipro, district Sanghar. For comparative study 15 , other farmers selected. The study aimed to know impact of compost on growth and yield of cotton crop. For this purpose, three varieties of cotton i.e MNH-886, FH-142 and IR-901 checked in same soil type situated in one village. Five dose of compost i.e. $500 \mathrm{Kg} / \mathrm{acre}, 400 \mathrm{Kg} / \mathrm{acre}, 300 \mathrm{Kg} / \mathrm{acre}, 200 \mathrm{Kg} /$ acre and $100 \mathrm{Kg} /$ acre checked at different farmers of same village and each dose of compost replicated at three times at three farmers making 15 farmers in total. Crop sown on same date April 5 and other inputs such as irrigation, pesticide and fertilizer applied in same quantity at same time in traditional way that was in vogue.

Compost made in the month of December by putting equal volume of above defined in puts in layers on the ground. In first step, five litters of liquid effective microorganisms (EM) suspension put into $20 \mathrm{~L}$ of tap water to multiply it for showering on each layer of material.
To boost up the material in the heap each layer showered with water. After making a solution, left for two hours to dilute properly with water. Secondly, an area of $8 \times 16$ feet cleaned from grass, dirt and other unwanted material for making heap of compost.The area for compost making selected that faced sunlight throughout the day so that fermentation process may go uninterrupted. Bar seem and Urea opted for scattering on each layer so, that fermentation process may speed up. The process of compost making started with putting 6 inches layer of Sugar Mill's press mud at bottom then same sized layer of FYM farmyard manure followed it. After that 6 inches layer of dry chopped sugarcane leaves put on it and $2 \mathrm{Kg}$ chopped green bar seem spread as source of nitrogen. Finally, $100 \mathrm{~g}$ urea spread out and then the layer was showered with $2 \mathrm{~L}$ of EM solution on it. Same way three layers of same material arranged in same way that made height of compost heap up to 4.5 feet. Then the heap covered with black coloured plastic polythene bag so, that it absorb maximum amount of sunlight and provide suitable environment to compost heap for fermentation. For controlled aeration in the heap, three perforated pipes of 4 inches diameter put in the middle of heap height in horizontal position. Both ends of pipe managed in a way that they remain outside of polythene bag that covered heap. The heap left for natural fermentation. After that, three pulverizations given to heap at the interval of 25 days. At each pulverization, dry areas showered with tap water. After 75 days, the compost was ready and it had completely changed its material into organic fertilizer.

Data collection process started from seed germination rate and ended at the calculating yield. Seed germination data taken after 2 weeks of sowing, plant growth and development data collected fortnightly and yield data noted at the time of final harvest, which is show in Table 1.

Application of compost. Application of compost done on two different times. Half of the compost applied at the time of final land preparation and other half applied after first irrigation. Application at both times done by broadcasting method.

Tabe 1. Seeds rate

\begin{tabular}{lll}
\hline \hline Varieties tested & Planting date & Seed rate \\
\hline MNH-886 & 05 April & $8 \mathrm{KG} /$ acre \\
FH-142 & 05 April & $8 \mathrm{KG} /$ acre \\
IR-901 & 05 April & $8 \mathrm{KG} /$ acre \\
\hline \hline
\end{tabular}




\section{Results and Discussion}

The data in Table 2 shows experimental results of different doses of compost (organic fertilizer) on $\mathrm{MNH}-$ 886 variety of cotton. Results revealed that the maximum seed germination observed $72.67 \%$ on T5 $(500 \mathrm{Kg} /$ acre $)$ and minimum on $\mathrm{T} 1(100 \mathrm{Kg}) 48.56$, same trend was shown in height of plants, where maximum height $138.93 \mathrm{~cm}$ recorded on $500 \mathrm{Kg}$ and minimum 93.02 $\mathrm{cm}$ on $\mathrm{T} 1(100 \mathrm{Kg})$. With reference to root length, it was found maximum $35.43 \mathrm{~cm}$ on $\mathrm{T} 5(500 \mathrm{Kg})$ and minimum root $25.24 \mathrm{~cm}$ on $\mathrm{T} 1(100 \mathrm{Kg})$. Highest numbers of branches 11.56 recorded on T5 $(500 \mathrm{Kg})$ and minimum $8.67 \mathrm{on}(100 \mathrm{Kg})$, similarly maximum numbers of bolls 45.78 recorded on $\mathrm{T} 5(500 \mathrm{Kg})$, whereas minimum 11.89 were recorded on $\mathrm{T} 1(100 \mathrm{Kg})$. Discussing the yield, maximum production $1840 \mathrm{Kg}$ was recorded on T5 $(500 \mathrm{Kg})$ and minimum $1040 \mathrm{Kg}$ recorded on $\mathrm{T} 1(100 \mathrm{Kg})$. Control plot found less than all treatments. Results found similar on all treatment, whereas $\mathrm{T} 5$ found significant on all parameters of experiment. The ANOVA showed that treatment mean found significant at 0.05 .

The data in Table 3 shows experiment results which reveal that the maximum numbers of seed germination 61.40 was observed on $\mathrm{T} 5(500 \mathrm{Kg})$ and minimum 51.03 was on $\mathrm{T} 1(100 \mathrm{Kg})$ discussing about other growth parameters, maximum height $123.34 \mathrm{~cm}$ was recorded on $\mathrm{T} 5(500 \mathrm{Kg})$ and minimum $107.10 \mathrm{~cm}$ was on $\mathrm{T} 1$ $(100 \mathrm{Kg})$, similar trend shown in other growth parameters such as maximum root length $37.45 \mathrm{~cm}$ determined on $\mathrm{T} 5(500 \mathrm{Kg})$ and minimum $26.17 \mathrm{~cm}$ recorded on $\mathrm{T} 1$ $(100 \mathrm{Kg})$. Same way, highest numbers of branches 23.10 recorded on $\mathrm{T} 5(500 \mathrm{Kg})$ and minimum 9.10 recorded on T1 $(100 \mathrm{Kg})$. Maximum numbers of bolls 25.90 recorded on $\mathrm{T} 5(500 \mathrm{Kg})$ and minimum 13.20 noted on T1 $(100 \mathrm{Kg})$, discussing about yield of FH142 maximum yield $1225 \mathrm{Kg}$ recorded on $\mathrm{T} 5(500 \mathrm{Kg})$ and minimum $1112 \mathrm{Kg}$ was on $\mathrm{T} 1(100 \mathrm{Kg})$. The results found similar on all treatment, whereas T5 was significant found on all parameters of experiment. The ANOVA results showed that treatment mean were found highly significant at 0.05 level indicate that all treatments almost FH-142 variety behind similar on all the treatments.

The data in Table 4 shows performance of IR 901 on different doses of compost. Result revealed that maximum seed germination 63.78 found on T5 (500 $\mathrm{Kg}$ ) and minimum 55.45 on $\mathrm{T} 1(100 \mathrm{Kg})$, showing same trend maximum height $117.60 \mathrm{~cm}$ recorded on T5 (500 $\mathrm{Kg})$ and minimum $105.34 \mathrm{~cm}$ noted on $\mathrm{T} 1(100 \mathrm{Kg})$. Similarly maximum root length $38.89 \mathrm{~cm}$ recorded on $\mathrm{T} 5(500 \mathrm{Kg})$ and minimum $24.90 \mathrm{~cm}$ on $\mathrm{T} 1(100 \mathrm{Kg})$.

Table 2. Impact of different doses of compost on growth and yield of cotton variety MNH-886

\begin{tabular}{lllllll}
\hline \hline Treatment & $\begin{array}{l}\text { Germination } \\
(\text { Mean } \pm \text { S.D })\end{array}$ & $\begin{array}{l}\text { Height }(\mathrm{cm}) \\
(\text { Mean } \pm \text { S.D })\end{array}$ & $\begin{array}{l}\text { Root length }(\mathrm{cm}) \\
(\text { Mean } \pm \text { S.D })\end{array}$ & $\begin{array}{l}\text { No. branches } \\
(\text { Mean } \pm \text { S.D })\end{array}$ & $\begin{array}{l}\text { No. bolls } \\
(\text { Mean } \pm \text { S.D })\end{array}$ & $\begin{array}{l}\text { Yield } \\
(\text { Mean } \pm \text { S.D })\end{array}$ \\
\hline T1- $100 \mathrm{Kg}$ & $48.56 \pm 1.35$ & $93.02 \pm 3.25$ & $25.24 \pm 0.76$ & $8.67 \pm 2.41$ & $11.89 \pm 0.85$ & $1042 \pm 4.76$ \\
T2- $200 \mathrm{Kg}$ & $54.62 \pm 0.98$ & $96.56 \pm 2.14$ & $27.98 \pm 0.14$ & $9.07 \pm 3.44$ & $16.98 \pm 0.45$ & $1150 \pm 3.11$ \\
T3- 300 Kg & $57.12 \pm 1.35$ & $100.34 \pm 2.35$ & $30.17 \pm 0.45$ & $10.07 \pm 0.90$ & $19.94 \pm 1.45$ & $1360 \pm 3.99$ \\
T4- 400 Kg & $62.89 \pm 2.04$ & $106.71 \pm 2.33$ & $32.92 \pm 1.34$ & $10.26 \pm 1.35$ & $27.85 \pm 2.90$ & $1760 \pm 4.89$ \\
T5- 500 Kg & $72.67 \pm 3.23$ & $138.93 \pm 2.76$ & $35.43 \pm 2.80$ & $11.56 \pm 1.17$ & $45.78 \pm 3.22$ & $1840 \pm 5.33$ \\
Over all mean & 59.172 & 107.112 & 30.348 & 9.926 & 24.488 & 1430.4 \\
Control & $40.16 \pm 1.55$ & $88.45 \pm 3.56$ & $21.42 \pm 0.34$ & $6.17 \pm 0.96$ & $8.13 \pm 0.78$ & $950 \pm 4.77$ \\
\hline \hline
\end{tabular}

Table 3. Impact of different doses of compost on growth and yield of cotton variety FH-142

\begin{tabular}{lllllll}
\hline \hline Treatment & $\begin{array}{l}\text { Germination } \\
(\text { Mean } \pm \text { S.D })\end{array}$ & $\begin{array}{l}\text { Plant height }(\mathrm{cm}) \\
(\text { Mean } \pm \text { S.D })\end{array}$ & $\begin{array}{l}\text { Root length }(\mathrm{cm}) \\
(\text { Mean } \pm \text { S.D })\end{array}$ & $\begin{array}{l}\text { No.branches } \\
(\text { Mean } \pm \text { S.D })\end{array}$ & $\begin{array}{l}\text { No. bolls } \\
(\text { Mean } \pm \text { S.D })\end{array}$ & $\begin{array}{l}\text { Yield } \\
(\text { Mean } \pm \text { S.D })\end{array}$ \\
\hline $\mathrm{T} 1-100 \mathrm{Kg}$ & $51.03 \pm 2.77$ & $107.1 \pm 3.22$ & $26.17 \pm 0.44$ & $9.1 \pm 0.17$ & $13.2 \pm 0.56$ & $1112 \pm 5.66$ \\
$\mathrm{~T} 2-200 \mathrm{Kg}$ & $53.56 \pm 3.21$ & $109.18 \pm 2.44$ & $28.12 \pm 0.45$ & $11.2 \pm 0.56$ & $15.07 \pm 1.80$ & $1125 \pm 3.09$ \\
$\mathrm{~T} 3-300 \mathrm{Kg}$ & $57.2 \pm 2.65$ & $113.4 \pm 3.22$ & $29.7 \pm 0.90$ & $13.33 \pm 0.99$ & $17.21 \pm 1.12$ & $1175 \pm 4.66$ \\
$\mathrm{~T} 4-400 \mathrm{Kg}$ & $59.31 \pm 2.67$ & $116.8 \pm 3.33$ & $33.2 \pm 1.10$ & $17.4 \pm 1.34$ & $21.3 \pm 1.33$ & $1190 \pm 7.44$ \\
$\mathrm{~T} 5-500 \mathrm{Kg}$ & $61.4 \pm 2.12$ & $123.34 \pm 2.33$ & $37.45 \pm 1.23$ & $23.1 \pm 1.78$ & $25.9 \pm 1.67$ & $1225 \pm 3.70$ \\
Over all mean & 56.5 & 113.96 & 30.928 & 14.826 & 18.536 & 1165.4 \\
Control & $49.1 \pm 3.21$ & $103.9 \pm 2.78$ & $21.4 \pm 1.89$ & $7.18 \pm 1.66$ & $11.1 \pm 1.09$ & $1060 \pm 3.55$ \\
\hline \hline
\end{tabular}


Table 4. Impact of different doses of compost on growth and yield of cotton variety IR-901

\begin{tabular}{lllllll}
\hline \hline Treatment & $\begin{array}{l}\text { Germination } \\
(\text { Mean } \pm \text { S.D })\end{array}$ & $\begin{array}{l}\text { Height } \\
(\text { Mean } \pm \text { S.D })\end{array}$ & $\begin{array}{l}\text { Root lengt } \\
(\text { Mean } \pm \text { S.D })\end{array}$ & $\begin{array}{l}\text { No. branches } \\
(\text { Mean } \pm \text { S.D })\end{array}$ & $\begin{array}{l}\text { No. bolls } \\
(\text { Mean } \pm \text { S.D })\end{array}$ & $\begin{array}{l}\text { Yield } \\
(\text { Mean } \pm \text { S.D })\end{array}$ \\
\hline T1- $100 \mathrm{Kg}$ & $55.45 \pm 2.77$ & $105.34 \pm 2.88$ & $24.9 \pm 1.11$ & $7.23 \pm 1.78$ & $9.21 \pm 0.33$ & $1012 \pm 4.33$ \\
T2- 200Kg & $57.19 \pm 1.66$ & $107.39 \pm 3.10$ & $26.31 \pm 1.09$ & $9.9 \pm 2.11$ & $11.2 \pm 0.81$ & $1020 \pm 5.21$ \\
T3- 300Kg & $58.3 \pm 2.10$ & $111.5 \pm 3.15$ & $31.8 \pm 1.98$ & $11.3 \pm 1.42$ & $13.1 \pm 1.12$ & $1070 \pm 5.99$ \\
T4- 400Kg & $61.5 \pm 2.99$ & $114.6 \pm 2.66$ & $35.7 \pm 1.35$ & $14.4 \pm 1.21$ & $14.7 \pm 1.45$ & $1090 \pm 4.19$ \\
T5- 500Kg & $63.78 \pm 3.21$ & $117.6 \pm 2.78$ & $38.89 \pm 1.45$ & $16.87 \pm 1.33$ & $16.2 \pm 1.40$ & $1125 \pm 6.32$ \\
Over all mean & 59.244 & 111.286 & 31.52 & 11.9 & 12.882 & 1063.4 \\
Control & $50.6 \pm 2.05$ & $101.45 \pm 2.33$ & $21.06 \pm 1.01$ & $5.34 \pm 0.56$ & $7.18 \pm 1.45$ & $960 \pm 4.77$ \\
\hline \hline
\end{tabular}

Discussing the growth of branches, highest numbers of branches 16.87 were recorded on $\mathrm{T} 5(500 \mathrm{Kg})$ and minimum 7.23 were found on $\mathrm{T} 1(100 \mathrm{Kg})$, same development is shown on number of bolls, where maximum numbers of bolls 16.20 recorded on T5 (500 $\mathrm{Kg})$ and minimum 9.21 were found on $\mathrm{T} 1(100 \mathrm{Kg})$. Recording yield of crop it was found maximum 1125 $\mathrm{Kg}$ on $\mathrm{T} 5(500 \mathrm{Kg})$ and minimum $1020 \mathrm{Kg}$ was observed on $\mathrm{T} 1(100 \mathrm{Kg})$. The results found similar on all treatment, whereas T5 was significant found on all parameters of experiment. The ANOVA results showed that treatment mean were found highly significant at 0.05 level indicate that all treatments almost IR-901 variety behind similar on all the treatments.

The data in Table 2 shows experimental results of different doses of compost (organic fertilizer) on MNH886 variety of cotton. Results revealed that the maximum seed germination observed $72.67 \%$ on T5 (500 Kg/acre) and minimum on $\mathrm{T} 1(100 \mathrm{Kg}) 48.56$, same trend was shown in height of plant, where maximum height 138.93 $\mathrm{cm}$ recorded on $500 \mathrm{Kg}$ and minimum $93.02 \mathrm{~cm}$ on $\mathrm{T} 1$ $(100 \mathrm{Kg})$. With reference to root length, it was found maximum $35.43 \mathrm{~cm}$ on $\mathrm{T} 5(500 \mathrm{Kg})$ and minimum root $25.24 \mathrm{~cm}$ on $\mathrm{T} 1(100 \mathrm{Kg})$. Highest numbers of branches 11.56 recorded on T5 $(500 \mathrm{Kg})$ and minimum 8.67 on $(100 \mathrm{Kg})$, similarly maximum numbers of bolls 45.78 recorded on T5 $(500 \mathrm{Kg})$, whereas minimum 11.89 were recorded on T1 $(100 \mathrm{Kg})$. Discussing the yield, maximum production $1840 \mathrm{Kg}$ was recorded on $\mathrm{T} 5$ $(500 \mathrm{Kg})$ and minimum $1040 \mathrm{Kg}$ recorded on T1 (100 $\mathrm{Kg})$. Results found similar on all treatment whereas; $\mathrm{T} 5$ found significant on all parameters of experiment.The data in Table-2 shows experiment results which reveal that the maximum numbers of seed germination 61.40 was observed on T5 $(500 \mathrm{Kg})$ and minimum 51.03 was on $\mathrm{T} 1(100 \mathrm{Kg})$, discussing about other growth parameters, maximum height $123.34 \mathrm{~cm}$ was recorded on $\mathrm{T} 5(500 \mathrm{Kg})$ and minimum $107.10 \mathrm{~cm}$ was on $\mathrm{T} 1$
$(100 \mathrm{Kg})$, similar trend shown in other growth parameters such as maximum root length $37.45 \mathrm{~cm}$ determined on $\mathrm{T} 5(500 \mathrm{Kg})$ and minimum $26.17 \mathrm{~cm}$ recorded on $\mathrm{T} 1$ $(100 \mathrm{Kg})$. Same way, highest numbers of branches 23.10 recorded on $\mathrm{T} 5(500 \mathrm{Kg})$ and minimum 9.10 recorded on T1 $(100 \mathrm{Kg})$. Maximum numbers of bolls 25.90 recorded on $\mathrm{T} 5(500 \mathrm{Kg})$ and minimum 13.20 noted on T1 (100 Kg), discussing about yield of FH 142 maximum yield $1225 \mathrm{Kg}$ recorded on $\mathrm{T} 5(500 \mathrm{Kg})$ and minimum $1112 \mathrm{Kg}$ was on $\mathrm{T} 1(100 \mathrm{Kg})$. The results found similar on all treatment, whereas T5 was significant found on all parameters of experiment. The data in Table 4 shows performance of IR901 on different doses of compost. Result revealed that maximum seed germination 63.78 found on $\mathrm{T} 5(500 \mathrm{Kg})$ and minimum 55.45 on $\mathrm{T} 1(100$ $\mathrm{Kg}$ ), showing same trend maximum height $117.60 \mathrm{~cm}$ recorded on $\mathrm{T} 5(500 \mathrm{Kg})$ and minimum $105.34 \mathrm{~cm}$ noted onT1 $(100 \mathrm{~kg})$. Similarly maximum root length $38.89 \mathrm{~cm}$ recorded on $\mathrm{T} 5(500 \mathrm{Kg})$ and minimum 24.90 $\mathrm{cm}$ on T1 $(100 \mathrm{Kg})$. Discussing the growth of branches, highest numbers of branches 16.87 were recorded on T5 $(500 \mathrm{Kg})$ and minimum 7.23 were found on T1 (100 $\mathrm{Kg}$ ), same development is shown on number of bolls, where maximum numbers of bolls 16.20 recorded on T5 $(500 \mathrm{Kg})$ and minimum 9.21 were found on T1 (100 $\mathrm{Kg}$ ). Recording yield of crop it was found maximum $1125 \mathrm{Kg}$ on $\mathrm{T} 5(500 \mathrm{Kg})$ and minimum $1020 \mathrm{Kg}$ was observed on $\mathrm{T} 1(100 \mathrm{Kg})$. The results found similar on all treatment, whereas T5 was significant found on all parameters of experiment. Present study agrees with Reddy et al. (2007) who used fresh and composted forms of poultry litter. Compost found as effective as urea in improving plant growth characteristics of cotton, such as plant height, number of main stem nodes, number of nodes above white flower and lint yield. Use of poultry litter rather than commercial fertilizer has the advantages of not only benefiting the growth of cotton, but also making use of an inexpensive local 
nutrient source and at the same time, ameliorating the ever-increasing poultry litter disposal problem Khalian et al. (2002) and applicated municipal solid waste (MSW) compost to agricultural land for cotton production. Application of compost done through broadcast method, which significantly reduced soil compaction as compared to the land not applied with compost. Use of compost increased the soil organic matter content and soil nitrogen content from six to fourteen weeks after planting. All treatments of added compost significantly increased seed cotton yield.

Conflict of Interest. The authors declare no conflict of interest.

\section{References}

Anonymous. 2013-14. Highlights of Pakistan Economic Survey. http://www.finance.gov.pk/survey/chapters_ 14/Highlights_ES_201314.pdf

Anonymous. 2008. The United States Composting Council. www.compostingcouncil.org Anonymous 2012. Textile Sector Study, The Pakistan Credit Rating Agency Limited.http://admin.umt.edu.pk/ Media/Site/STD1/FileManager/OsamaArticle/jan uary/jan23/Textile_SS_Dec_12.pdf

Arain, G.N. 2012. Centre Pivot Irrigation System, Valley irrigation Pakistan Private Limited, http://www. valleyirrigationpakistan.com/wp-content/uploads/ $2012 / 09 /$ COT TON - CULTIVATION-IN PAKISTAN.pdf

Ghazala, N., Rasul, G. 2010. Recent water requirement of cotton crop in Pakistan, Pakistan Journal of Meteorology, 6: 75-84.12http://pjm.pmd.gov.pk/ index.php/pjm/article/view/135

Diaz, L.F., De Bertoldi, M. 2007. Compost Science and Technology, $1^{\text {st }}$ edition 8:25-48 pphttps://www. elsevier.com/ books/compost-science-andtechnology/diaz/978-0-08-043960-0

Reddy, K.C., Malik, R. K., Reddy,S.S., Nyakatawa, E.Z. 2007. Cotton growth and yield response to nitrogen applied through fresh and composted poultry litter. The Journal of Cotton Science, 11: 26-34. https:// www.cotton.org/journal/200711/1/upload/jcs11-26.pdf

Khalilian, A., Sullivan, M.J., Mueller, J.D., Shiralipour, A., Wolak, F.J., Williamson, R.E., Lippert, R.M. 2002. Effects of surface application of MSW compost on cotton production-soil properties, plant responses and nematode management, Journal of Compost Science \& Utilization, 10: 3. https://www. tandfonline.com/doi/abs/10.1080/1065657X.2002. 10702089

Kumar, S.P., Singh, P. C., Gupta, M., Sinha, A., Vaish, A., Shukla, A., Singh, N., Krishna, T.S. 2011. Influence of earthworm culture on fertilization potential $\mathrm{xx}$ and biological activities of vermicomposts prepared from different plant wastes. Journal of Plant Nutrition and Soil Science, 174: 420-429. https://onlinelibrary.wiley.com/doi/abs/10. 1002/jpln.201000174

Pugliese, M., Liu, B. P., Gullino, M. L., Garibaldi, A. 2011. Microbial enrichment of compost with biological control agents to enhance suppressiveness to four soil-borne diseases in greenhouse. Journal for Plant Diseases and Plant, 2: 45-50.https://link. springer.com/article/10.1007/BF03356380

Vinceslas-Akpa, M.,Loquet, M. 1997. Organic matter transformation in lignocellulosic waste products composted or vermi-compost (Eiseniafetida andrei): chemical analysis and 13C CPMAS NMR spectroscopy. Soil Biology and Biochemistry, 29: 751-758. https://www.sciencedirect.com/science/ article/abs/pii/S0038071796002015 